\title{
Stress and stressors of medical student near-peer tutors during courses: a psychophysiological mixed methods study
}

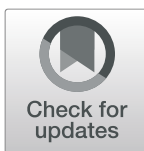

\author{
Jan Hundertmark ${ }^{1 *} \mathbb{D}$, Simone Alvarez ${ }^{1}$, Svetla Loukanova ${ }^{2}$ and Jobst-Hendrik Schultz ${ }^{1}$
}

\begin{abstract}
Background: Structured peer-led tutorial courses are widespread and indispensable teaching methods that relieve teaching staff and contribute to the development of students' competencies. Nevertheless, despite high general stress levels in medical students and associated increases in psychopathology, specific knowledge of peer tutors' additional burdens is very limited.
\end{abstract}

Methods: Sixty student near-peer tutors from two structured peer-teaching programmes volunteered to participate. On multiple occasions in three different course sessions, we assessed tutors' subjective stress, affective state, heart rate variability, and salivary cortisol. Additionally, tutors named everyday and course-specific stressors, which were evaluated by means of content analyses.

Results: The study participation rate was high (63\% of all active tutors). The participating tutors are socially well adapted and resilient individuals. They report a variety of stressors such as time pressure, participant characteristics, teacher role demands, and study requirements, but nevertheless display only moderate psychological and physiological stress that decreases over sessions. Tutors' negative affect in sessions is low; their positive affect is consistently high for senior as well as novice tutors. Tutors rate their courses' quality as high and quickly recover after sessions.

Conclusions: Tutors successfully cope with teaching-associated and everyday life demands. The results corroborate the viability and success of current peer-teaching programmes from the tutors' perspective. This study is the first to comprehensively quantify tutors' stress and describe frequent stressors, thus contributing to the development of better peer teaching programmes and tutor qualification training.

Keywords: Peer assisted learning, Peer teaching, Tutors, Stress, Medical students, Cortisol, Heart rate variability, Content analysis, Mixed methods

\section{Background}

Peer teaching, commonly understood as educational arrangements in which a student teaches one or more fellow students [1], has a long history in both medical and academic education in general $[2,3]$. It is generally perceived as an effective, feasible, and cost-efficient learning method that alleviates demands on clinical instructors and improves overall clinical experiences for students [4-7].

One important and prevalent near-peer teaching setting is structured peer-led tutorial courses, in which experienced

\footnotetext{
* Correspondence: jan.hundertmark@med.uni-heidelberg.de

${ }^{1}$ Clinic for General Internal Medicine and Psychosomatics, University Hospital Heidelberg, Im Neuenheimer Feld 410, 69120 Heidelberg, Germany
} Full list of author information is available at the end of the article and trained students (student peer or near-peer tutors, hereinafter referred to as tutors) instruct small groups in subjects such as communication and anatomy or in clinical skills $[1,8,9]$. These tutorial courses have, if properly implemented, the potential to be as effective as conventional staff-led classes [6, 10-13]. Tutors are usually highly motivated and engaged $[14,15]$ and possess high cognitive and social congruence [16]: Their awareness and familiarity with their tutees' current level of knowledge and study situation allows them to adapt their use of didactics, language, and exercise difficulty; similarities in age, life situation, and qualification result in a more personal and amicable learning atmosphere with less fear or shame of asking questions or making mistakes. Tutors themselves also benefit from

(c) The Author(s). 2019 Open Access This article is distributed under the terms of the Creative Commons Attribution 4.0 International License (http://creativecommons.org/licenses/by/4.0/), which permits unrestricted use, distribution, and 
their work, apart from mere financial compensation. They usually undergo some form of selection or training process $[17,18]$ and gain communication, teaching, and clinical skills that can lead to improved grades, patient interaction, learning behaviour, self-reflection, and even personal resilience [19-24].

Notwithstanding these apparent benefits, tutorship is time-consuming and places additional demands and responsibilities on tutors, including leadership, prioritisation, and identifying and coping with own mistakes or weaknesses [24]. Despite the growing prevalence of structured peer-led tutorial courses, researchers have paid little attention to these additional challenges. This is especially surprising against the background of medical students' high stress levels [25-27].

Stress can be defined as an organism's response to certain triggering factors that result from interaction with the environment [28]. It aims at enabling individuals to perceive and cope with threats and challenges [29]. Stress encompasses non-specific sympathetic activation, leading to increased heart rate and blood pressure, the release of catecholamines and corticosteroids, along with psychological changes like heightened alertness or increased attention [30], as well as other fine-tuned, individualised response patterns [31]. In moderate levels, stress can be a source of motivation and enhance learning [32]; therefore, it can be beneficial for medical training [33, 34]. However, excessive stress can lead to physical, emotional, and mental health problems [35] and is associated with an increased prevalence of psychopathology in medical students, such as anxiety, burnout, depression, and substance abuse [26, 36-40]. For instance, 30 to $40 \%$ of medical students experience relevant psychopathological symptoms [41]. Similarly, Koehl-Hackert et al. [42] found a burnout prevalence of $20 \%$ in German final year medical students.

Stress stems from environmental events, commonly referred to as stressors, that are appraised by a person as taxing or exceeding his or her resources [43, 44]. Typical stressors reported by medical students are information overload, financial debt, lack of leisure time, curriculum and course organisation, work-related pressures including work relationships and career choices [45]. The diverse requirements of tutoring activities, such as preparing teaching materials, giving presentations, leading a group, resolving in-group conflicts, and completing compulsory training, potentially add further burdens to this array; however, whether these requirements are experienced as stimulating or harmful strongly depends on tutors' individual resources and coping capacities [28, 44].

This study focusses on two structured near-peer-teaching programmes at Heidelberg Medical Faculty: "Anatomie am Lebenden plus" ["living anatomy plus"] and abdominal ultrasonography. Anatomie am Lebenden plus ( $\mathrm{AaL}^{\text {plus }}$ ) consists of sequential two-week practical seminars which are mandatory in all four preclinical semesters [46]. Over five sessions, students acquire basic physical examination techniques, take medical histories of standardised simulation patients [47], and approach and solve medical cases using problem-based learning methods [48]. Aal ${ }^{\text {plus }}$ tutorial courses have ten to twelve participants and are taught by a team of two tutors, typically a novice and a senior tutor. Abdominal ultrasonography is a highly popular one-week elective in which preclinical students learn to handle ultrasonic devices, locate standard scan planes, perform basic clinical ultrasound tests, and identify pathologies or abnormalities. Tutors teach groups of five participants for two hours each day. Senior tutors work alone, whereas novice tutors are obliged to observe a senior tutor's course session before teaching the same unit himself under that senior tutor's supervision. In both AaL ${ }^{\text {plus }}$ and sonography, tutors follow a set thematic structure; however, they are required to prepare study material, revise and present course content, answer participants' questions, give feedback, moderate practice phases, and handle group dynamics. Teaching an AaL ${ }^{\text {plus }}$ course takes a tutor about $8 \mathrm{~h}$ plus about $9 \mathrm{~h}$ of preparation in total; sonography courses require about $15 \mathrm{~h}$ plus about $10 \mathrm{~h}$ of preparation. Tutors typically take on two to four $\left(\mathrm{AaL}^{\text {plus }}\right)$ or one or two (sonography) courses per semester. Moreover, the compulsory preceding qualification places additional burdens on tutors' time: They need to complete 40 to $50 \mathrm{~h}$ of unpaid didactical, communicational, and technical training before being allowed to teach. All $\mathrm{AaL}^{\text {plus }}$ and sonography courses take place in the late afternoons and evening.

Taken together, tutor programmes offer a multitude of potential teaching benefits, but may place considerable additional demands on tutors selected from the already burdened population of medical students; however, the extent or nature of tutors' specific stress has not yet been systematically investigated. This study aims to fill this research gap by comprehensively assessing tutors' stressors and psychophysiological stress responses in a naturalistic setting. In addition to this descriptive assessment, we hypothesised that unexperienced (novice) tutors experience more stress than experienced (senior) tutors, that stress levels drop over course days, and that certain personality traits (extraversion, low neuroticism, resilience, low perfectionism, and secure attachment) are negatively correlated with tutor stress.

\section{Methods}

\section{Participants}

We invited all active tutors from the $\mathrm{AaL}^{\text {plus }}$ and sonography programmes to participate. $36 \mathrm{AaL}^{\text {plus }}$ tutors (17 novice, 19 senior tutors, 17 female, 19 male; out of 53 $\mathrm{AaL}^{\text {plus }}$ active tutors in total, participation rate 68\%) and 24 sonography tutors (11 novice, 13 senior tutors, 15 female, 9 
male; out of 42 active sonography tutors in total, participation rate $57 \%$ ) volunteered. Mean age was 22.8 years $(S D=2.6)$; senior tutors were on average 1.4 years $(S D=2.5)$ older and had already taught $7.0 \quad(S D=6.0)$ courses. In addition to the given time requirements for teaching, study participation took tutors an extra three hours, for which they received financial compensation.

\section{Procedure}

Recruitment and data collection took place in winter semester 2016/2017. At an initial session, participants were informed about the study procedure, gave their written consent, completed a first set of personality questionnaires, and assigned one of their tutorial courses for data collection. The actual stress assessment took place on days 1,2 , and 4 of the respective course. For $\mathrm{AaL}^{\text {plus }}$, this included sessions on history taking, physical examination (neurological or locomotor system), and problem-based learning. For sonography, the respective session topics were aorta and vena cava, liver and gall bladder, and kidney and urinary bladder. On each survey day, data collection followed the same routine, as depicted in Fig. 1. An investigator was present at all times to assist tutors with study procedures, saliva samples, and the equipment of the heart rate monitors, which had to be worn during a course session's whole measurement period. Participants arrived $30 \mathrm{~min}$ before the beginning of their respective session, started heart rate recording, completed the first set of measures, and continued session preparation as usual. An extensive assessment followed directly after teaching, including written reports of stressors experienced in the respective session. Subsequently, participants entered a 30-min recovery phase. We instructed them to remain in

\begin{tabular}{|c|c|c|c|c|}
\hline & $\sum_{>}^{\infty}$ & $\sum_{0}^{\infty}$ & $\begin{array}{l}0 \\
0 \\
0 \\
0 \\
0 \\
0\end{array}$ & 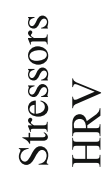 \\
\hline $30^{\prime}$ before start & $\bullet$ & $\bullet$ & $\bullet$ & \\
\hline Start of session & $\bullet$ & & & \\
\hline First section (30') & & & & \\
\hline $\begin{array}{l}\text { Middle section } \\
\left(30^{\prime} \text { to } 60^{\prime}\right)\end{array}$ & & & & \\
\hline Final section (30') & & & & \\
\hline End of session & $\bullet$ & $\bullet$ & $\bullet$ & $\bullet$ \\
\hline Recovery phase (30’) & & & & \\
\hline End of recovery phase & $\bullet$ & $\bullet$ & $\bullet$ & \\
\hline
\end{tabular}

Fig. 1 Overview on measurement points/periods on all three survey days. Abbreviations: see Instruments section silence and relax in a sitting position. They were free to think about anything and let their minds wander, but should not engage in mental work like planning their day or revising any study matter. Afterwards, participants completed a final assessment and stopped heart rate recording. Following the last survey day, participants additionally reported every-day stressors and were conclusively debriefed.

\section{Design}

This study followed a mixed-methods design, combining quantitative and qualitative research methods and both psychological and physiological data. We assessed the extent and time profiles of tutors' stress using repeated quantitative measures before, during, and after tutorial sessions; moreover, the subsequent half-hour rest period served to assess the extent and speed of psychophysiological recovery. The employed psychological measures are subjective stress (VAS-Stress; for abbreviations: see Instruments section), positive and negative affect (PANAS), and written reports of relevant stressors during and outside of courses; the physiological measures are salivary cortisol and heart rate variability (HRV). To investigate potential protective or risk factors, we assessed selected aspects of participants' personality using validated questionnaires.

\section{Instruments \\ VAS-stress}

Visual analogue scales (VAS) are continuous, easy-to-use one-item interval scales that allow self-assessments of internal feelings, perceptions, or sensations that are difficult to phrase or measure on scales with predetermined intervals. VAS are typically composed of a $100 \mathrm{~mm}$ horizontal line on which subjects can rate their current mental state, with end anchors such as not at all stressed and extremely stressed in this study $[49,50]$. Its validity, reliability, and sensitivity to change have been shown for various scopes of application, including subjective stress $[51,52]$. The VAS-Stress's theoretical scale range is 0 to 10. In this study, participants further used a similar scale to rate the subjective quality of their respective courses.

\section{PANAS}

Positive and negative affect are the two dominant dimensions of emotional experience [53, 54]. In this study, we used the established Positive And Negative Affect Schedule's (PANAS) short version. The PANAS measures a person's current affective state using 5-level Likert scales on two dimensions consisting of five items each $[55,56]$ : active, determined, attentive, inspired, and alert for Positive Affect (PA) and afraid, nervous, upset, hostile and ashamed for Negative Affect (NA). The PANAS's theoretical scale range is 1 to 5 . 


\section{Salivary cortisol}

Due to its sensitivity to physical or psychological stress as well as its easy traceability in saliva, cortisol has been the most widely used biomarker in stress studies for decades [57-59]. As effector hormone of the hypothalamic-pituitary-adrenocortical (HPA) axis, which mediates slower, but more enduring aspects of the stress response, it has wide-ranging effects on the whole body [60-63]. Cortisol level increases become peripherally detectable only five minutes after the stressor and reach their maximum ten to $30 \mathrm{~min}$ after stressor cessation [64]. Salivary cortisol is highly correlated with blood cortisol levels [65-67], especially with the free cortisol fraction that is able to cross the blood-brain barrier and bind to receptors at structures responsible for high-level cognitive functions such as learning, memory, and emotion processing [64, 68, 69].

In this study, we used synthetic fibre swabs (Salivetten ${ }^{\circ}$ by Sarstedt) as the most convenient, economic, and valid method of saliva collection $[67,70]$. Since cortisol levels react to physical activity as well as glucose and drug intake [71-77], we instructed participants to strictly refrain from workout, the consumption of alcohol, caffeine, and nicotine on survey days, as well as eating $30 \mathrm{~min}$ and drinking five minutes before taking samples [78]. All saliva samples were collected after sessions, deep-frozen, and analysed in the Heidelberg University Hospital's Steroid Lab.

Cortisol levels follow a pronounced circadian rhythm, with a sharp rise after awakening and a linear decline from afternoon to evening $[64,79]$, which needs to be taken into account when using cortisol as a stress marker. In this study, participants autonomously took three $\left(\mathrm{AaL}^{\text {plus }}\right)$ or four (sonography) saliva samples at specified times on the late afternoon and evening of a rest day, usually Sunday, following the same instructions for sample taking as on other survey days. The resulting sample values allowed us to model linear time profiles of participants' normal cortisol levels, which then served as a baseline against which we compared participants' cortisol levels before and after courses.

\section{Heart rate variability}

Heart rate variability (HRV) is the physiological phenomenon of varying time intervals between heartbeats even at constant output or resting conditions. HRV is a non-invasive, reliable, and valid index of cardiac vagal tone and hence parasympathetic activity [80]; it reflects the heart's capacity to adapt to changing circumstances and unforeseen stimuli [81]. Independent associations of vagally mediated HRV with general mortality and morbidity as well as work environment stressors have been consistently shown [82-86]. Short term HRV analyses, as used in this study, reflect the autonomic balance shift during acute mental stress, comprising increased sympathetic arousal and parasympathetic withdrawal.

Modern heart rate monitors usually consist of wireless chest strap electrodes and additional equipment, e.g. a watch, for data storage. They provide researchers with an affordable, robust, reliable, and highly valid means to record HRV data $[87,88]$. HRV analysis software is able to determine common time domain and frequency domain measures [86, 89]. In this study, we used Polar V800 ${ }^{\circ}$ sports watches, a Microsoft Excel ${ }^{\oplus}$ macro [90] for data transformation, and the Kubios HRV $2.2^{\circ}$ analysis software [91] with medium-level artefact correction settings and the smoothing-priors de-trending method [92]. The root mean square of successive differences in interbeat intervals (RMSSD) [86, 89] served as the primary HRV measure. The RMSSD is largely independent from the measurement period's duration [93]; however, we chose a standardised length of $30 \mathrm{~min}$ for analysis wherever possible (see Fig. 1).

\section{Participant characteristics}

For further correlational analyses, we assessed participants' personality, perfectionism, resilience, and attachment style before the start of the study. We employed the German 21-item short version of the Big Five Inventory (BFI-K) for assessing personality [94-96]; for perfectionism, the German 8-item short version of the Revised Almost Perfect Scale (SAPS-R, subscales standards, i.e. high performance expectations, and discrepancy, i.e. self-critical performance evaluations) [97, 98]; for resilience, the German 13-item short version of the Resilience Scale (RS 13, subscales personal competence and acceptance of self and life) [99, 100]; and for attachment style, the 16-item German version of the Adult Attachment Scale (AAS, subscales Depend, indicating ability to trust in others and depend on them to be available when needed, Anxiety in relationships, and Close, indicating ability to be comfortable with closeness and intimacy) [101, 102]. Additionally, we measured chronic stress with the German version of the Trier Inventory for the Assessment of Chronic Stress (TICS), a 57-item 10-scales questionnaire including one screening scale [103]. All instruments possess satisfactory to excellent psychometric criteria and have been validated in numerous studies (for further references see [94-103]).

\section{Data analysis}

Prior to data analysis, we performed a thorough data screening, including checks for normality, linearity, floor effects, and outliers, as well as independence and homogeneity between measures. We detected no significant outliers, limitations, or violations of the general linear 
model assumptions, except for slightly skewed cortisol level distributions; however, the analysis methods used in this study are generally seen as sufficiently robust $[104,105]$.

To adjust cortisol values for measurement time and participants' individual circadian rhythms, we first determined baseline cortisol levels from participants' rest day cortisol samples by means of hierarchical linear modelling (HLM) [106]. HLM is an extension of linear regression modelling for hierarchical data structures, such as observations nested in participants, that should be employed if the dataset's intraclass correlation (ICC) is above .05 . We first computed a restricted maximum likelihood estimation model with measurement time as main predictor and compared it to a null model without predictors. With the resulting model, we then calculated individual time-dependent cortisol reference values, against which we next compared the respective participants' cortisol levels at the different measurement points on survey days. The final net cortisol values represent the teaching-specific HPA axis activation.

We analysed participants' quantitative stress profiles (VAS-Stress, PA, NA, net cortisol, and HRV) with repeated-measures analyses of variances (RM-ANOVAs), which is used to assess several or repeated measurements of the same participants under different conditions. Given this method's sensitivity to missing values, we imputed lost data (2.4\% of all data, no indications of non-random missing patterns) using the expectation maximisation procedure [107] before running the RM-ANOVAs. Afterwards, we also tested for violations of the sphericity of repeated measures assumption using Mauchly's test and, where required, corrected the analyses' degrees of freedom using the Huynh-Feldt procedure. Finally, we investigated the potential influence of tutorship experience as well as protective personality factors by means of covariate analyses.

We used the statistic package R 3.3.2 with the lme4 library for HLM and SPSS 25.0 for all other purposes, with a general significance level of $\alpha=.05$. As to qualitative data, we performed three content analyses with tutors' written reports on their course-specific (AaL ${ }^{\text {plus }}$ and sonography) and everday life stressors. In these analyses, one researcher $(\mathrm{JH})$ clustered participants' statements into theme groups to create inductive category systems [108].

\section{Results}

\section{Sample characteristics}

As multiple $t$-tests revealed that participant characteristics did not differ depending on course type ( $A a L^{\text {plus }}$ and sonography), tutor experience (senior and novice tutors), age, or gender, we aggregated descriptive data over these factors. Comparisons of participant characteristics with respective norm values indicate that tutors are mostly outgoing, secure, competent and conscientious individuals with a balanced lifestyle. Their reports on chronic stress do not differ significantly from general population values, except for slightly higher pressure to perform and lower social overload. Additional file 1: Table S1 within the online supplementary material gives a comprehensive overview on participants' descriptive data as well as norm sample values and comparisons.

\section{Psychological stress}

Table 1 shows the RM-ANOVA results for all psychological stress measures. Tutors report medium subjective stress levels of $M=3.48(S D=2.36) 30 \mathrm{~min}$ and $M=3.80$ $(S D=2.42)$ immediately before session start. After session completion, they report lower values, $M=1.97$ $(S D=1.84)$, and $M=1.22(S D=1.41)$ after recovery. Stress levels progressively decrease over course days, as shown in Fig. 2. They are higher for sonography tutors than for AaL ${ }^{\text {plus }}$ tutors, overall $M=3.23(S D=2.33)$ vs. overall $M=2.21(S D=2.19)$, and higher for novice than for senior tutors, $M_{\Delta}=0.70$. The general stress pattern is similar but not equal over conditions, as indicated by significant interaction effects: On earlier days, with low experience, and in sonography tutors, stress values start higher but decline more steeply (see Table 2). Taken together, tutors experience moderate stress levels and recover well after sessions.

Tutors' positive affect is generally high, both $30 \mathrm{~min}$ before the start of the sessions, $M=3.45(S D=0.65)$, and after the end of the sessions, $M=3.36(S D=0.80)$. However, positive affect drops to $M=2.48(S D=0.71)$ after the recovery phase, presumably due to lower activation and wakefulness. It also decreases slightly, but significantly over measurement days, as shown in Fig. 3 and Table 3. Nevertheless, these decreases are moderate and senior tutors report the same amount of positive affect as novice tutors. Sonography tutors do not differ systematically in positive affect from $\mathrm{AaL}^{\text {plus }}$ tutors, except for a slightly more pronounced decrease after recovery.

Tutors report low negative affect that decreases over a course's measurement period: $M=1.41(S D=0.45)$ before the start of sessions, $M=1.18(S D=0.35)$ after sessions, and $M=1.15(S D=0.36)$ after recovery phases. Furthermore, it declines over measurement days, as shown in Fig. 4 and Table 4. Tutor experience does not generally influence negative affect levels, with the exception of the first measurement $30 \mathrm{~min}$ before session start, where novice tutors show higher levels than senior tutors; $t(178)=2.89, p=.006$, see Table 1: no Exp main effect but significant interaction effect Time*Exp. Taken together, even though tutors demonstrate moderate levels of psychological (VAS-Stress) and physiological arousal, they experience only very limited negative affect. 
Table 1 Test statistics for RM-ANOVAs (psychological measures, main and first order interaction effects)

\begin{tabular}{|c|c|c|c|c|c|c|c|c|c|}
\hline \multirow[t]{2}{*}{ Factors } & \multicolumn{3}{|c|}{ VAS-Stress } & \multicolumn{3}{|c|}{ Positive Affect } & \multicolumn{3}{|c|}{ Negative Affect } \\
\hline & $F$ & $d f$ & $p$ & $F$ & $d f$ & $p$ & $F$ & $d f$ & $p$ \\
\hline Time & 98.00 & $2.44,136.62$ & $<.001$ & 137.67 & 2,112 & $<.001$ & 75.44 & $1.66,92.97$ & $<.001$ \\
\hline Time*Type & 8.04 & $2.44,136.62$ & $<.001$ & 4.10 & 2,112 & .02 & 2.12 & $1.66,92.97$ & .13 \\
\hline Time*Exp & 8.00 & $2.44,136.62$ & $<.001$ & 1.52 & 2,112 & .22 & 5.18 & $1.66,92.97$ & .01 \\
\hline Day & 26.24 & 2,112 & $<.001$ & 11.07 & 2,112 & $<.001$ & 5.29 & $1.56,87.26$ & .01 \\
\hline Day*Type & 1.83 & 2,112 & .17 & 1.00 & 2,112 & .37 & 0.11 & $1.56,87.26$ & .85 \\
\hline Day*Exp & 0.68 & 2,112 & .50 & 1.18 & 2,112 & .33 & 0.33 & $1.56,87.26$ & .67 \\
\hline Time*Day & 7.68 & $4.87,272.79$ & $<.001$ & 1.30 & 4,224 & .27 & 4.68 & $3.18,178.26$ & .003 \\
\hline Type & 0.92 & 1,56 & .002 & 0.39 & 1,56 & .54 & 0.66 & 1,56 & .42 \\
\hline Exp & 4.04 & 1,56 & $<.05$ & 2.18 & 1,56 & .15 & 1.24 & 1,56 & .27 \\
\hline Type*Exp & 3.42 & 1,56 & .07 & 0.07 & 1,56 & .79 & 0.97 & 1,56 & .33 \\
\hline
\end{tabular}

Note. F-test statistics of main and first order interaction effects with Visual Analogue Scale (VAS-Stress) scores, Positive Affect, and Negative Affect as respective dependent variables. Independent variables: Time Point of measurement, Day Day of measurement, Type tutor type (AaL ${ }^{\text {plus }}, n=36, v^{2}$. sonography, $\left.n=24\right)$, Exp tutor experience (senior, $n=32$ vs. novice tutors, $n=28$ ). Mauchly tests for sphericity: VAS: $W_{\text {Time }}=.62, p<.001, W_{\text {Day }}=92, p=.09, W_{\text {Time*Day }}=.31, p<.001 ;$ Positive Affect: All W's $>.81, p^{\prime} s>.27$; Negative Affect: All $W$ 's $<.63, p^{\prime} s<.001$. Within-subject factor statistics corrected for nonsphericity (where appropriate) using the Huynh-Feldt procedure, F F-statistic, $d f$ (corrected) numerator and denominator degrees of freedom, $p p$-value

\section{Physiological stress}

Tutors' absolute salivary cortisol levels were moderate, ranging from 0.15 to $12.86 \mathrm{ng} / \mathrm{ml}, M=2.13(S D=1.72)$. Careful data screening showed no signs of systematic hypo- or hypercortisolism that would impair interpretability; for instance, only $1.8 \%$ of cortisol data were above 8.0 $\mathrm{ng} / \mathrm{ml}$. Intra-assay variance was $4.04 \%$ on average, inter-assay variance was below 15\%. As described above, we applied a HLM to determine individual time-dependent low-activity cortisol reference values and identified a random coefficients model with time as random and fixed factor as the best fitting model, AIC = 727.3, log-likelihood $=-357.7, d f=198$; predictor statistics $t_{\text {time.fixed }}(198)=-5.79, \quad p<.001 ; \quad \operatorname{Var}_{\text {time.random }}=0.0038$ :

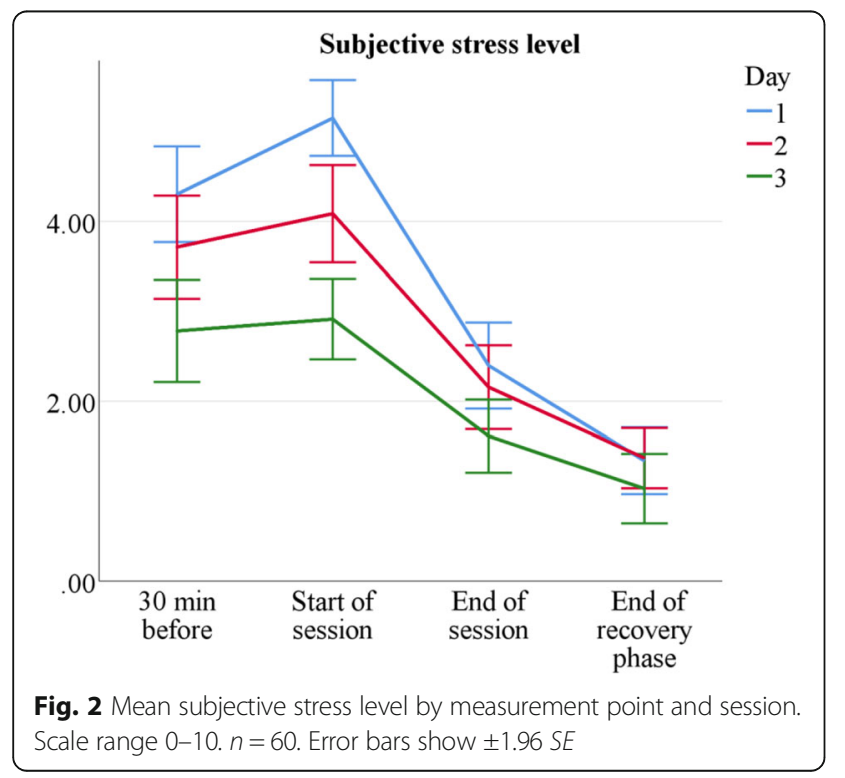

This model was clearly superior to a random intercept null model, AIC $=753.4$, $\log$-likelihood $=-373.7, d f=201$, ICC $=.65 ; X^{2}(3)=32.05, p<.001$. Tutor type was tentatively included as predictor into the analysis, but again removed as it proved nonsignificant, $t(197)=1.17, p=.24$.

Table 5 shows the RM-ANOVA results for all physiological stress measures. Tutors' overall HPA axis activation (in comparison to individual rest day value) by teaching was low and differed significantly between $\mathrm{AaL}^{\text {plus }}$ tutors, $M=-.43(S D=1.82)$, and sonography tutors, $M=0.73$ (SD $=1.68$ ). Negative net cortisol values do not necessarily imply total relaxation, but lower physiological arousal in comparison to a chosen Sunday, which may be relatively active for some tutors.

Similar to the psychological indices, stress measured by salivary cortisol generally declines over the measurement period. It is higher before the start of the session and slowly

Table 2 VAS-Stress means over conditions

\begin{tabular}{llll}
\hline & Day 1 & Day 2 & Day 3 \\
\hline AaL $^{\text {plus }}$ & & & \\
30 min before & $3.76 \pm 2.53$ & $3.06 \pm 2.55$ & $2.49 \pm 2.38$ \\
Start of session & $3.96 \pm 2.27$ & $3.12 \pm 2.50$ & $1.93 \pm 1.75$ \\
End of session & $1.77 \pm 1.89$ & $1.66 \pm 1.46$ & $1.29 \pm 1.44$ \\
$\quad$ End of recovery phase & $1.00 \pm 1.35$ & $1.20 \pm 1.22$ & $1.28 \pm 1.72$ \\
Sonography & & & \\
30 min before & $4.88 \pm 1.77$ & $4.29 \pm 1.75$ & $3.01 \pm 1.96$ \\
Start of session & $6.25 \pm 1.50$ & $4.97 \pm 1.79$ & $3.80 \pm 2.04$ \\
End of session & $3.08 \pm 2.05$ & $2.66 \pm 2.18$ & $1.95 \pm 1.69$ \\
End of recovery phase & $1.54 \pm 1.45$ & $1.51 \pm 1.40$ & $0.75 \pm 1.00$ \\
\hline
\end{tabular}

Note. $n_{\text {AaL }}=36, n_{\text {Sono }}=24$. Stress level means and standard deviations by tutor type, session, and measurement point 


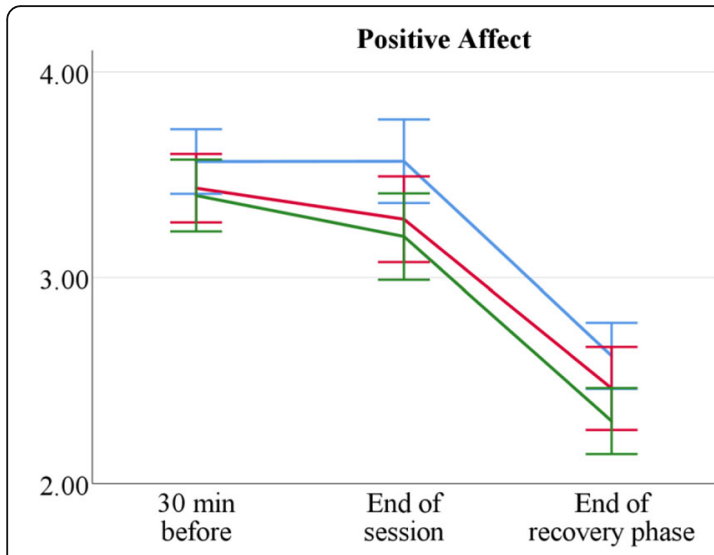

Fig. 3 Mean positive affect by measurement point and session. $n=60$. Scale range $1-5$. Error bars show \pm 1.96 SE

drops until its end, except for the first day, on which cortisol levels only fall after the recovery phase. Figure 5 visualises this pattern; Table 6 reveals more details about the differences between tutor types. On day 3 , sonography tutors show relatively high cortisol values, presumably due to an additional free practice session offered to course participants on that day, which requires tutors to be present at least one hour earlier for support and assistance. Sonography tutors' raised cortisol levels after the first course day can be explained by taking the HPA axis's delayed reactivity into account: They match tutors' high subjective stress directly before session start on that day (Table 2). Taken together, sympathetic stress levels are altogether moderate; they are mostly lower than on a typical rest day for $\mathrm{AaL}^{\text {plus }}$ tutors and slightly higher for sonography tutors.

The RMSSD, as main parameter for HRV and thus parasympathetic activity, revealed moderate overall physiological stress that decreases over the measurement period. The RMSSD's total mean (recovery phase excluded) was $M=34.82(S D \pm 14.68)$; only two participants showed an individual mean lower than 20. For comparison, a typical RMSSD rest value in healthy populations is $42(S D=15)$ [109]. In a sample

Table 3 PA means over conditions

\begin{tabular}{llll}
\hline & Day 1 & Day 2 & Day 3 \\
\hline AaL $^{\text {plus }}$ & & & \\
30 min before & $3.44 \pm 0.59$ & $3.43 \pm 0.65$ & $3.35 \pm 0.73$ \\
End of session & $3.61 \pm 0.78$ & $3.31 \pm 0.83$ & $3.25 \pm 0.85$ \\
End of recovery phase & $2.66 \pm 0.60$ & $2.58 \pm 0.81$ & $2.53 \pm 0.62$ \\
Sonography & & & \\
30 min before & $3.68 \pm 0.68$ & $3.43 \pm 0.65$ & $3.45 \pm 0.58$ \\
End of session & $3.51 \pm 0.79$ & $3.25 \pm 0.74$ & $3.15 \pm 0.71$ \\
End of recovery phase & $2.54 \pm 0.74$ & $2.32 \pm 0.72$ & $2.05 \pm 0.63$ \\
\hline
\end{tabular}

Note. $n_{\text {Aat }}=36, n_{\text {Sono }}=24$. Positive affect (PA) means and standard deviations by tutor type, day, and measurement point

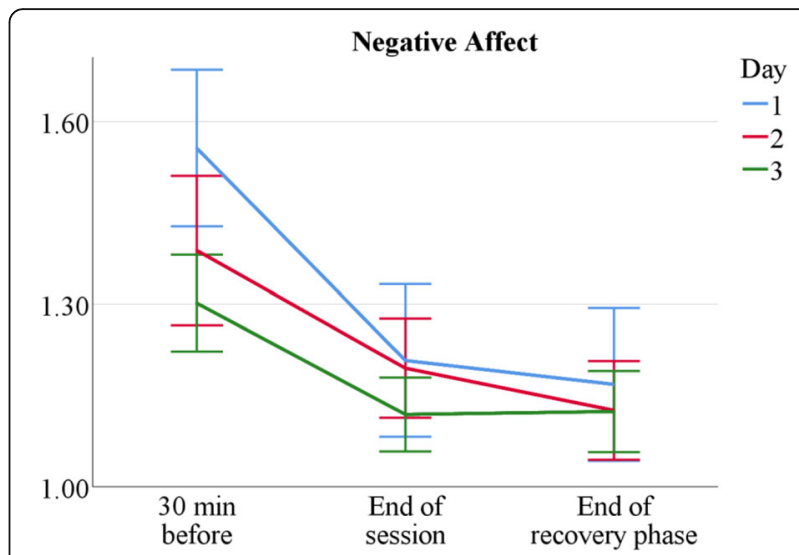

Fig. 4 Mean negative affect by measurement point and session. $n=60$. Scale range 1-5. Error bars show \pm 1.96 SE

of first semester medical students, $M_{\text {age }}=19.80\left(S D_{\text {age }}=\right.$ 2.12), Huhn et al. [110] found an RMSSD of $M=59.45$ $(S D=35.31)$ in a rest condition, $M=47.21 \quad(S D=29.68)$ during a seminar, and $M=15.47(S D=9.25)$ during an oral examination. Therefore, tutors' physiological stress in courses was slightly higher than in typical attentive states, but clearly lower than in specific high demand situations. Figure 6 visualises the RMSSD profiles found in this study; Table 7 reveals detailed data for AaL ${ }^{\text {plus }}$ and sonography tutors. On average, the two tutors types do not differ, but a significant interaction effect (Time*Type) indicates a stronger recovery of sonography tutors after sessions. Day 3 , however, is an exception from this trend, due to course structure variations that reflect in the data: On this day, $\mathrm{AaL}^{\text {plus }}$ tutors hosted a problem-based learning session, which requires a more passive and laid-back facilitator role except for the session closing; conversely, sonography tutors had less time pressure but extended session duration because of the additional free practice hour taking place on that day. Furthermore, sonography tutors showed higher baseline RMSSD values at the initial measurement point, $M_{\text {Sono }}=65.63 \quad\left(S D_{\text {Sono }}=32.67\right)$, $M_{\mathrm{AaL}}=50.66,\left(S D_{\mathrm{AaL}}=26.01\right) ; F(1,56)=4.32, p=.04$.

Table 4 NA means over conditions

\begin{tabular}{llll}
\hline & Day 1 & Day 2 & Day 3 \\
\hline AaL ${ }^{\text {lus }}$ & & & \\
30 min before & $1.56 \pm 0.62$ & $1.42 \pm 0.59$ & $1.30 \pm 0.36$ \\
$\quad$ End of session & $1.21 \pm 0.56$ & $1.19 \pm 0.35$ & $1.16 \pm 0.27$ \\
$\quad$ End of recovery phase & $1.22 \pm 0.59$ & $1.17 \pm 0.38$ & $1.21 \pm 0.32$ \\
Sonography & & & \\
30 min before & $1.54 \pm 0.29$ & $1.34 \pm 0.22$ & $1.30 \pm 0.24$ \\
End of session & $1.21 \pm 0.34$ & $1.20 \pm 0.24$ & $1.08 \pm 0.15$ \\
End of recovery phase & $1.17 \pm 0.48$ & $1.08 \pm 0.14$ & $1.04 \pm 0.10$ \\
\hline
\end{tabular}

Note. $n_{\text {Aat }}=36, n_{\text {Sono }}=24$. Negative affect (NA) means and standard deviations by tutor type, day, and measurement point 
Table 5 Test statistics for RM-ANOVAs (physiological measures, main and first order interaction effects)

\begin{tabular}{|c|c|c|c|c|c|c|}
\hline \multirow[t]{2}{*}{ Factors } & \multicolumn{3}{|c|}{ Net Cortisol } & \multicolumn{3}{|l|}{ RMSSD } \\
\hline & $F$ & $d f$ & $p$ & $F$ & $d f$ & $p$ \\
\hline Time & 14.43 & $1.79,99.95$ & $<.001$ & 119.45 & $2.52,140.97$ & $<.001$ \\
\hline Time*Type & 1.84 & $1.79,99.95$ & .17 & 3.66 & $2.52,140.97$ & .02 \\
\hline Time*Exp & 0.98 & $1.79,99.95$ & .37 & 0.84 & $2.52,140.97$ & .46 \\
\hline Day & 5.08 & $1.58,88.47$ & .01 & 7.78 & $1.62,90.91$ & .002 \\
\hline Day*Type & 1.40 & $1.58,88.47$ & .25 & 2.89 & $1.62,90.91$ & .07 \\
\hline Day*Exp & 0.95 & $1.58,88.47$ & .37 & 0.10 & $1.62,90.91$ & .86 \\
\hline Time*Day & 2.41 & $3.33,186.41$ & .06 & 0.79 & $2.39,134.00$ & .48 \\
\hline Type & 11.06 & 1,56 & .002 & 0.00 & 1,56 & .95 \\
\hline Exp & 0.79 & 1,56 & .38 & 0.81 & 1,56 & .37 \\
\hline Type*Exp & 1.03 & 1,56 & .32 & 0.96 & 1,56 & .33 \\
\hline
\end{tabular}

Note. F-test statistics of main and first order interaction effects with net cortisol and root mean square of successive differences (RMSSD) in interbeat intervals as respective dependent variables. Independent variables: Time Point of measurement Day Day of measurement, Type tutor type (AaL ${ }^{\text {plus }}, n=36$, vs. sonography, $n=24$ ), Exp tutor experience (senior, $n=32$ vs. novice tutors, $n=28$ ). Mauchly tests for sphericity: Net cortisol: All W's <.79, p's $\leq .001$; RMSSD: All W's $<.68, p^{\prime} s<.001$. Within-subject factor statistics corrected for nonsphericity (where appropriate) using the Huynh-Feldt procedure, F F-statistic, $d f$ (corrected) numerator and denominator degrees of freedom, $p p$-value

The disappearance of this difference implies a larger decrease of parasympathetic arousal during teaching. Taken together, these results indicate higher stress in sonography tutors when compared to $\mathrm{AaL}^{\text {plus }}$ tutors.

All other HRV indices display similar profiles and closely mirror the results obtained for the RMSSD: parasympathetic activity slowly increases both over single course sessions, with a strong rise during the recovery phase, as well as over measurement days, especially on day 3. A comprehensive overview on all HRV data can be found in Additional file 2: Table S2 within the online supplementary material.

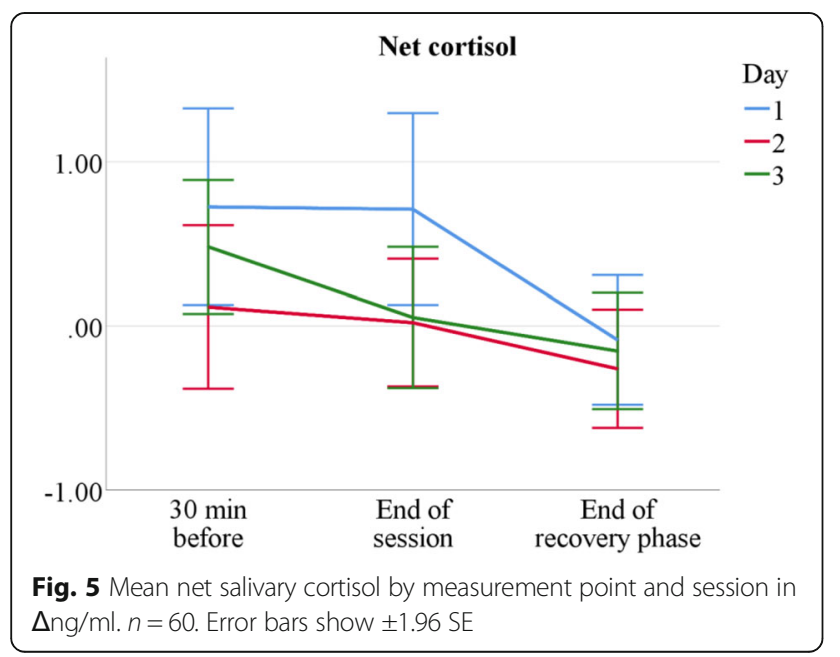

Table 6 Net cortisol means over conditions

\begin{tabular}{llll}
\hline & Day 1 & Day 2 & Day 3 \\
\hline AaL $^{\text {plus }}$ & & & \\
30 min before & $0.34 \pm 2.10$ & $-0.38 \pm 2.00$ & $-0.42 \pm 1.57$ \\
End of session & $-0.04 \pm 2.50$ & $-0.63 \pm 1.51$ & $-0.70 \pm 1.59$ \\
$\quad$ End of recovery phase & $-0.49 \pm 1.78$ & $-0.73 \pm 1.51$ & $-0.78 \pm 1.49$ \\
Sonography & & & \\
30 min before & $1.14 \pm 2.54$ & $0.64 \pm 1.80$ & $1.40 \pm 1.54$ \\
End of session & $1.53 \pm 1.92$ & $0.68 \pm 1.52$ & $0.80 \pm 1.76$ \\
End of recovery phase & $0.32 \pm 1.13$ & $0.19 \pm 1.30$ & $0.49 \pm 1.18$ \\
\hline
\end{tabular}

Note. $n_{\text {AaL }}=36, n_{\text {Sono }}=24$. Net cortisol means and standard deviations by tutor type, day, and measurement point

\section{Correlations between personality and stress measures}

To determine the influence of personality on individuals' stress, we sequentially included the assessed personality variables as covariates into the RM-ANOVAs reported above. The correlations with the different stress measures thus obtained are adjusted for measurement point, measurement day, tutor type, and tutor experience, and shown in Table 8.

Extraversion was correlated with high positive and low negative affect, which is not surprising, given the interactive and interpersonal nature of teaching demands. Furthermore, we found extraversion to be the only personality trait correlated with a physiological stress index, the RMSSD. Agreeableness was positively correlated with reported positive affect. Resilience was a protective factor against subjective stress and negative affect. Other personality traits, namely conscientiousness, openness,

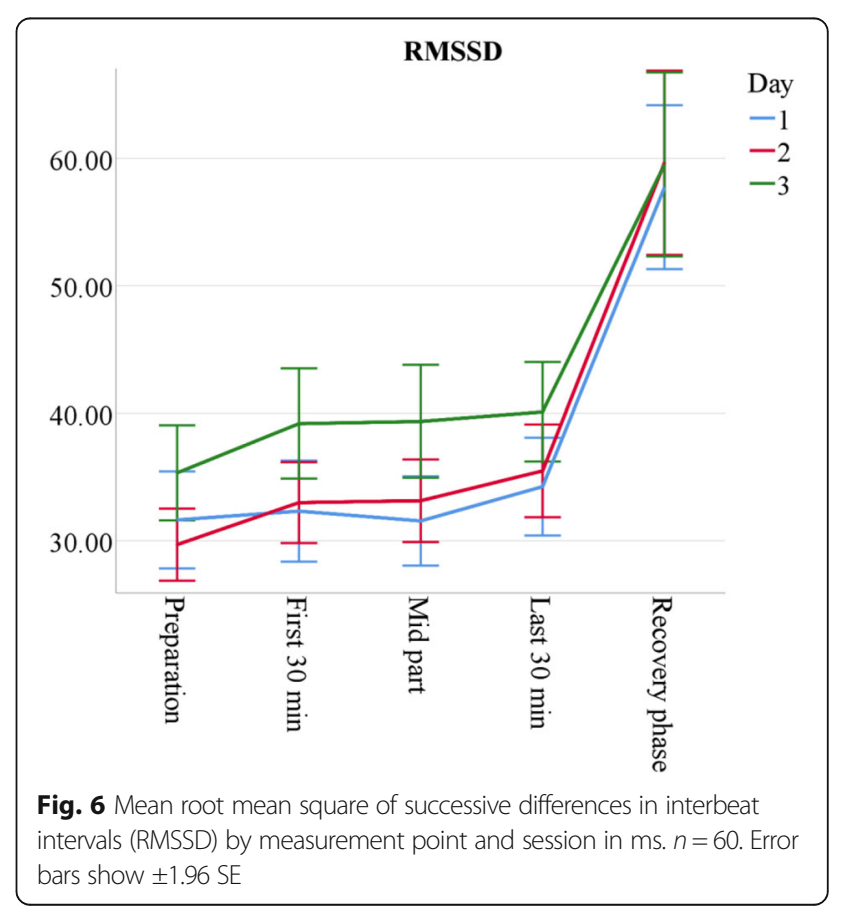


Table 7 RMSSD means over conditions

\begin{tabular}{llll}
\hline & Day 1 & Day 2 & Day 3 \\
\hline AaL $^{\text {plus }}$ & & & \\
30 min before & $30.13 \pm 14.72$ & $33.46 \pm 11.85$ & $37.27 \pm 15.43$ \\
First 30 min of session & $31.49 \pm 13.80$ & $30.30 \pm 10.38$ & $41.68 \pm 18.28$ \\
Mid part of session & $34.55 \pm 15.15$ & $32.43 \pm 10.55$ & $43.87 \pm 19.89$ \\
Last 30 min of session & $37.62 \pm 16.32$ & $36.10 \pm 13.20$ & $37.64 \pm 15.42$ \\
Recovery phase & $53.79 \pm 21.84$ & $52.85 \pm 22.43$ & $63.52 \pm 32.95$ \\
Sonography & & & \\
30 min before & $32.98 \pm 14.57$ & $26.29 \pm 10.01$ & $33.60 \pm 12.25$ \\
First 30 min of session & $32.96 \pm 17.28$ & $35.56 \pm 14.52$ & $36.96 \pm 13.35$ \\
Mid part of session & $28.79 \pm 10.24$ & $33.95 \pm 14.83$ & $35.12 \pm 10.92$ \\
Last 30 min of session & $31.18 \pm 12.08$ & $35.04 \pm 15.56$ & $42.28 \pm 14.52$ \\
Recovery phase & $61.96 \pm 28.34$ & $67.90 \pm 34.00$ & $55.75 \pm 18.83$ \\
\hline
\end{tabular}

Note. $n_{\text {AaL }}=36, n_{\text {Sono }}=24$. Root mean square of successive differences (RMSSD) means and standard deviations by tutor type, day, and measurement point

attachment style, and perfectionism, did not or only in tendency show correlations with stress measures.

The tutors evaluated their courses' quality generally as high, $M=7.76(S D=1.36)$. Overall course quality ratings did not differ between senior and novice tutors, $F(1,56)=$ 1.42, $p=.24$; however, they were significantly correlated with subjective stress measures, $r_{\mathrm{VAS}}=-.20, r_{\mathrm{PA}}=.34, r_{\mathrm{NA}}$ $=-.29$, but not with physiological stress measures, $r_{\text {Cortisol }}$ $=-.09, r_{\mathrm{RMSSD}}=.02$.

\section{Stressors and life events}

Three category systems resulted from inductive content analyses [108] of the questionnaires' free entry fields: Stressors during $\mathrm{AaL}^{\text {plus }}(3 \times 36$ entries) and sonography courses $(3 \times 24$ entries) as well as tutors' general everyday life stressors (60 entries). Multiple mentions per entry field were possible.

Table 9 lists the resulting categories of stressors during sessions along with category descriptions, mentions counts and exemplary mentions. Stressors found in both courses were time pressure, leadership role demands, uncertainties in medical knowledge, as well as single participants' characteristics; however, time pressure was more prevalent in sonography courses and leadership role demands in $\mathrm{AaL}^{\text {plus }}$ courses. Furthermore, organisational difficulties (like late arrivals or technical problems) and coordination within the teaching team posed additional challenges for $\mathrm{AaL}^{\text {plus }}$ tutors, whereas sonography tutors had to handle bad sonographic conditions in some ultrasound models. After 41 (38\%) AaL ${ }^{\text {plus }}$ sessions and $23(32 \%)$ sonography sessions, tutors reported no stressors.

Table 10 presents content analysis results for general stressors. On average, tutors report about two relevant general stressors, mostly related to their academic life: Studying for exams, teaching and preparing peer teaching, and working for their doctorate are the most prevalent stressors. Beyond that, the other categories provide insight into further daily challenges encountered by tutors.

Table 8 Correlations of personality and adjusted stress measures

\begin{tabular}{|c|c|c|c|c|c|}
\hline & VAS-Stress & Positive Affect & Negative Affect & Cortisol & RMSSD \\
\hline \multicolumn{6}{|l|}{ Personality: BFI-K } \\
\hline Extraversion & -.16 & $.31^{*}+$ & $-.44^{* * *} \dagger$ & -.11 & $.32^{*}+$ \\
\hline Neuroticism & $.26^{*}$ & -.06 & $.28^{*}$ & -.11 & .00 \\
\hline Conscientiousness & -.18 & .22 & $-.29^{*}$ & -.14 & .14 \\
\hline Agreeableness & .03 & $.36^{* *}+$ & -.06 & .07 & -.13 \\
\hline Openness & -.04 & -.01 & -.09 & -.08 & .07 \\
\hline \multicolumn{6}{|l|}{ Attachment style: AAS } \\
\hline Depend & -.22 & .14 & -.24 & -.05 & -.02 \\
\hline Anxiety & $.27^{*}$ & -.11 & .19 & -.10 & .00 \\
\hline Close & $-.30^{*}$ & .13 & $-.28^{*}$ & .05 & -.02 \\
\hline \multicolumn{6}{|l|}{ Resilience: RS 13} \\
\hline Competence & $-.31^{*}$ & $.30^{*}$ & $-.48^{* * *} \dagger$ & .04 & .06 \\
\hline Acceptance & $-.35^{* *}+$ & .11 & $-.37^{* *}+$ & .10 & -.13 \\
\hline \multicolumn{6}{|l|}{ Perfectionism: SAPS-R } \\
\hline Standards & -.08 & .03 & -.24 & .04 & .00 \\
\hline Discrepancy & .25 & -.18 & .18 & -.01 & -.10 \\
\hline
\end{tabular}

Note. Pearson-correlations of personality and stress measures, adjusted for measurement times, tutor type and experience. VAS Visual Analogue Scale, RMSSD root mean square of successive differences in interbeat intervals

$n=60 .{ }^{*} p<.05 .{ }^{* *} p<.01 .{ }^{* * *} p<.001$. $\dagger$ significant after Bonferroni-Holm-corrections for multiple comparisons [114] 
Table 9 Category system of stressors during sessions

\begin{tabular}{|c|c|}
\hline $\mathrm{AaL}^{\text {plus }}$ & \\
\hline Group characteristics (13) & $\begin{array}{l}\text { Passive or sluggish groups, loud and } \\
\text { inattentive groups, or strong differences in } \\
\text { prior knowledge. "Very silent participants, } \\
\text { hardly any volunteers for history taking } \\
\text { exercises." }\end{array}$ \\
\hline $\begin{array}{l}\text { Team teaching } \\
\text { coordination (13) }\end{array}$ & $\begin{array}{l}\text { Teaching partner shows low involvement, is } \\
\text { too dominant, or omits preparatory meetings. } \\
\text { "I took on the largest part of teaching because } \\
\text { I felt my partner is not prepared." }\end{array}$ \\
\hline $\begin{array}{l}\text { Organisational } \\
\text { conditions (13) }\end{array}$ & $\begin{array}{l}\text { Last-minute preparations, especially when } \\
\text { devices do not function properly, or late } \\
\text { arrivals of standardised patient actors or } \\
\text { students. } \\
\text { "The projector's sound did not work; we then } \\
\text { showed the video on a laptop } \\
\text { computer instead." }\end{array}$ \\
\hline $\begin{array}{l}\text { Leadership role } \\
\text { demands (10) }\end{array}$ & $\begin{array}{l}\text { Group instruction ( } 6 \text { mentions), speaking in } \\
\text { front of participants, or giving feedback. } \\
\text { "Keeping an eye on participants: who needs } \\
\text { further assistance and is too shy to ask." }\end{array}$ \\
\hline Time pressure(9) & $\begin{array}{l}\text { Lack of time both during a session and due } \\
\text { to the additional workload for preparation } \\
\text { and teaching. } \\
\text { "Too little time at the end of the session." "Time } \\
\text { lost due to teaching: I have an exam on Friday." }\end{array}$ \\
\hline $\begin{array}{l}\text { Uncertainties in medical } \\
\text { knowledge (9) }\end{array}$ & $\begin{array}{l}\text { Limits of own medical knowledge, mostly } \\
\text { encountered when preparing and giving } \\
\text { presentations. } \\
\text { "A student's question about thrombosis } \\
\text { prophylaxis which / could not answer." }\end{array}$ \\
\hline Supervision (5) & $\begin{array}{l}\text { Routine supervisions by faculty staff member. } \\
\text { "Supervision was stressful." "The supervision } \\
\text { made me nervous, though mostly before the } \\
\text { start of the session." }\end{array}$ \\
\hline $\begin{array}{l}\text { Participant } \\
\text { characteristics (3) }\end{array}$ & $\begin{array}{l}\text { Single participants' character traits or } \\
\text { behaviour. "One student was very dominant, } \\
\text { wants to convey extra knowledge but goes } \\
\text { beyond the scope of the course; the group } \\
\text { was partly irritated." }\end{array}$ \\
\hline Personal discomfort (2) & Hunger or minor illness. "Dry cough." \\
\hline
\end{tabular}

\section{Sonography}

Time pressure (16)

Ultrasound difficulties (9)

Poor participant performance (9)
Tight schedule and extensive subject matter, little buffer for delays or participants' knowledge gaps.

"Much content, little time. I got delayed at the gall bladder." "Time management and order."

Bad sonographic conditions that complicate detecting structures and locating standard scan planes.

"Both ultrasound demonstrations were poor (overlaying intestinal gases)."

Unprepared and unskilled participants. " Participants need a lot of assistance" "Participants were not properly prepared and had forgotten the last days' contents."

Difficulties in motivating participants and directing group processes. "Keeping participants attentive so that nobody gets
Table 9 Category system of stressors during sessions (Continued)

\begin{tabular}{ll}
\hline & $\begin{array}{l}\text { bored." "When students could not answer } \\
\text { theoretical questions." }\end{array}$ \\
Uncertainties in & $\begin{array}{l}\text { Limits of own medical knowledge, i.e. when } \\
\text { identifying structures or assisting participants. } \\
\text { medical knowledge (5) } \\
\text { did not know how to concretely assist } \\
\text { participants." }\end{array}$ \\
Participant & $\begin{array}{l}\text { Single participants' character traits or behaviour. } \\
\text { characteristics (4) }\end{array}$ \\
"Problems of understanding with a foreign student." \\
"A student's constant private conversations".
\end{tabular}

Total mentions: 56; "None" or no mention: 23

Note. Resulting categories of stressors during sessions, based on 108 free entry fields for Aa ${ }^{\text {plus }}$ tutors and 72 for sonography tutors. Respective numbers of mentions within each category are shown in parentheses, exemplary mentions in italics

Taken together, tutors experience a wide array of stressors. However, specific numbers differ widely: Most tutors report multiple stressors, yet a noticeable proportion mentions no or only limited stressors.

\section{Discussion}

\section{Principal findings}

The tutors examined in this study are mostly outgoing, secure, and resilient young adults (see Table 1). Except for slightly higher pressure to perform and lower social overload, their self-reports on chronic stress resemble general population values; hence, the participating tutors appear to dispose of sufficient resources, including leadership experience, to meet the demands and challenges of teaching fellow students. We further showed that, on a correlational level, the tutors' above-average extraversion and resilience was a protective factor. Even though this study did not focus on mental health or group comparisons, the results do not indicate the heightened psychopathological burden commonly found in medical student populations [25-27]. This is not altogether surprising, given that Heidelberg and numerous other medical schools stringently select students with outstanding academic and social abilities for their tutor programmes and extensively prepare them for their tutoring activities in special training [17].

The comparison of two tutorial course types shows both similarities and differences in tutors' stress experience. Sonography tutors are more stressed than $\mathrm{AaL}^{\text {plus }}$ tutors (see Tables 2 and 6) and, as expected, novice tutors are more than senior tutors (see Tables 1 and 5); however, despite occasional stress peaks, tutors generally experience teaching as stimulating and only moderately stressful (see Figs. 2, 3, 4, 5 and 6). 
Table 10 Category system of general stressors

\begin{tabular}{|c|c|}
\hline Studies and exams (29) & $\begin{array}{l}\text { Study workload, clerkships, compulsory courses, and upcoming examinations. } \\
\text { "Lots of compulsory courses." "Exam week in both natural medicine and emergency care." }\end{array}$ \\
\hline Teaching and preparation (18) & $\begin{array}{l}\text { Preparing and holding courses, as well as the necessary time for preparation. } \\
\text { "AaL plus sessions } 3 x / \text { week." "The preparation for the tutorial courses was very demanding." }\end{array}$ \\
\hline Doctorate (13) & $\begin{array}{l}\text { Applying for and preparing a doctorate, research and laboratory work, and writing a thesis. } \\
\text { "Much work in the lab, especially a presentation of the last months' results." }\end{array}$ \\
\hline Part-time jobs (12) & $\begin{array}{l}\text { Mostly as undergraduate assistants or shifts at hospital wards. } \\
\text { "Additional night shifts, altogether about } 4 x \text { last month; at times only two hours of sleep." }\end{array}$ \\
\hline $\begin{array}{l}\text { Travel, family visits and } \\
\text { Erasmus stays (8) }\end{array}$ & $\begin{array}{l}\text { Larger travels, Erasmus study stays abroad, family visits. } \\
\text { "Return from my Erasmus stay." "First time at home for Christmas for three years." }\end{array}$ \\
\hline $\begin{array}{l}\text { Housing search } \\
\text { and moving (8) }\end{array}$ & $\begin{array}{l}\text { Flat viewing and moves. "I had to move houses, rent a transporter, carry furniture, arrange the rental contract, } \\
\text { and register at the residents' office - all parallel to the sonography course." }\end{array}$ \\
\hline $\begin{array}{l}\text { Illness (own and family } \\
\text { members') (6) }\end{array}$ & $\begin{array}{l}\text { Health restrictions and worries. "I had a serious flu." "My mother's illness. Due to her language barriers, I hac } \\
\text { to help her with her rehab application." }\end{array}$ \\
\hline Engagements (5) & Engagement in social projects or the faculty's student body. "Tasks in the student council." \\
\hline Other (14) & $\begin{array}{l}\text { Some mentions could not be summarised in any category, such as selection interviews for scholarships, } \\
\text { personal conflicts, break-ups, imminent deadlines, or sports competitions. }\end{array}$ \\
\hline Unspecific (10) & General stress without a specified stressor. "Psychological stress due to life circumstances." \\
\hline
\end{tabular}

mentions: 123: "None" or no mention: 13

Note. Resulting categories of general everyday life stressors, based on 60 free entry fields. Respective numbers of mentions within each category are shown in parentheses, exemplary mentions in italics

All employed stress measures revealed similar profiles: Psychological and physiological stress are moderately high before the start of the session, decline to its end and subside after the recovery phase; moreover, stress decreases over course days. This corresponds to a normal and healthy stress response cycle; especially the cessation of remaining arousal during recovery indicates sufficient and successful coping [28, 80]. These findings are independent from course type or tutor experience, with minor exceptions on the third measurement day: Sonography tutors' cortisol levels slightly increase, probably due to additional teaching demands, whereas AaLplus tutors show noticeably high RMSSD values on that day, which is likely to reflect their more passive, moderating role during problem-based learning sessions.

Differences in demands between course types show not only in quantitative data but also in tutors' qualitative statements. AaL ${ }^{\text {plus }}$-specific stressors encompass difficult group dynamics or team-teaching coordination problems; within sonography courses, tight schedules and extensive teaching contents pose the largest challenges, especially when course participants perform poorly or sonographic conditions are unfavourable. Teaching-related stressors found in both course types are time pressure, leadership position demands, and participant as well as group characteristics.

However, even though tutors name a multitude of course-related stressors, all participating tutors, independent of course type or tutor experience, report high positive affect that only declines very slightly over the measurement period. This indicates that positive emotions during teaching do not decline through routine, waning interest, or other habituation effects. Furthermore, the tutors' self-rated course quality is generally high. This indicates a constantly high personal involvement which does not diminish over time, for instance due to habituation, routine, or insufficient stimulation.

Taken together, even though peer teaching poses noticeable demands on tutors, it does not seem to raise stress to levels that endanger students' mental health $[26,35,38,111]$. To the contrary, the results suggest that tutors experience a well-matched balance of environmental challenges and individual capacities, which is known to have potentially stimulating, engaging, and generally beneficial effects on learning and performance [32-34]. This demonstrates the possibility of creating peer teaching programmes that are viable, beneficial, and healthy not only for participating students, but also for tutors themselves, at least given an adequate selection and training process.

\section{Strengths and limitations}

This study's multidimensional assessment, utilising a variety of psychophysiological stress indices at multiple measurement points and days in a naturalistic setting, provides a comprehensive and valid view on tutors' stress. All stress markers possess good to excellent quality criteria; moreover, known variations in course agendas, for instance at the third day, are closely reflected in stress measures, which further corroborates measurement validity. Cortisol measures, however, show relatively large standard errors, potentially due to the moderate stress levels that may not have sufficed to evoke a stronger HPA 
axis response. Given the large number of repeated measures, the study's sample size $(n=60)$ was sufficient for all analyses. The pseudonymisation of participant data protected from social desirability effects.

The online measurement of HRV data allowed close tracking of individual stress profiles. Unfortunately, the study design did not permit assignment of single events or specific situations to variations in these profiles; therefore, we could only determine the average individual parasympathetic activity during teaching. However, tutors' qualitative statements close this gap by providing detailed insight into the nature and frequency of stressors they experience in teaching and their everyday life.

Qualitative analyses are interpretative by nature: Although data categorisation procedures are rule- and theory-guided, it is possible that different analysis considerations yield different results. Moreover, only one author performed the analyses in this study. Nonetheless, due to the narrow and clearly circumscribed research questions and the unambiguous participant answers, this interpretative element was minimised.

As the study participation rates of $\mathrm{AaL}^{\text {plus }}(68 \%)$ and sonography (57\%) tutors are very high (63\% overall), this study allows valid assertions about stress and stressors in these two structured tutorial programmes. However, medical faculties' organisational structures and fields of application for peer teaching are diverse, which is why other tutor programmes come with potentially different requirements and demands on tutors that may result in different stressors and stress profiles [17].

\section{Directions for future research and application}

Past research on peer assisted learning has focussed on exploring and establishing diverse areas of application, as well as determining their feasibility and efficacy. As a next step, researchers should additionally take health and stress in different tutor samples into account. Chronic stress and its associated health problems are highly prevalent among physicians and often start to manifest in study years [40-42]; moreover, especially the combined burdens of frequent, multiple stressor exposure seem to promote mental illness in medical students $[112,113]$. The results presented in this study may serve as a benchmark against which quantitative and qualitative stress measures from future studies can be compared.

Although the tutors examined in this study cope successfully, differences in stress levels exist, depending on course type and tutor experience. Experience and habituation influence stress and negative affect, but not positive affect. We further showed that even well-structured peer-teaching courses induce numerous additional stressors, that in other contexts or for some individuals may exceed a healthy coping capacity
[28, 44]. Moreover, we found that low stress was significantly correlated with higher course quality, at least on a subjective level. For these reasons, curriculum designers and staff responsible for peer teaching programmes should mind the potential burdens of tutoring and, if necessary, make efforts to mitigate stress and initiate adequate prevention strategies. A more precise knowledge of stressors frequently encountered by peer teachers, as presented in this study, can support staff in achieving this objective. For instance, in our tutor training, we prepare tutors both in terms of medical-technical as well as leadership skills, such as handling time pressure, group dynamics, difficult participant characteristics, and other tutor role demands. In addition to tailored training, tutor supervision may specifically address these frequent stressors. Moreover, health and coping can already be taken into account when recruiting new tutors: Our results suggest that extraversion and general resilience are two suitable selection criteria.

\section{Conclusion}

Structured peer-led tutorial courses, an effective, feasible, and cost-efficient peer teaching method, put various demands on student tutors, such as time pressure, leadership, and course preparation. Nonetheless, tutors display various indicators of successful coping: moderate psychological and physiological stress, consistently high positive affect without indicators for loss of interest, and good recovery after sessions. Tutors' actual stress levels partly depend on experience and course characteristics. They self-evaluate their courses positively. These results corroborate the viability and success of current peer-teaching programmes from the tutors' perspective.

This study presents a comprehensive overview on peer tutors' stress and stressors: an extensive quantification of psychophysiological stress levels provides a benchmark for future research, a detailed account of frequent stressors contributes to the development of better peer teaching programmes, tutor qualification training, or stress prevention strategies.

\section{Additional files}

Additional file 1: Table S1. Sample characteristics and comparisons to norm samples. Table S1 presents descriptive data about personality (BFI-K), attachment style (AAS), resilience (RS 13), perfectionism (SAPS-R) and chronic stress (TICS) in the tutor sample and norm samples. It further shows sample comparison test statistics and descriptive data on tutors' lifestyle (physical activity, relationship status, prior teaching and leadership experience, sleep per night, substance use, and weekly time for studies, hobbies, and other activities). (DOCX $25 \mathrm{~kb}$ )

Additional file 2: Table S2. Heart rate measures in the different course sections on all three measurement days. Table $\$ 2$ gives a comprehensive overview on all heart rates measures and derived indices on all measurement occasions. The reported data comprise time domain measures (mRR, RMSSD, heart rate, SDNN, and pNN50) as well as frequency domain measures (VLF, LF, 
and HF component, LF/HF ratio) obtained with autoregressive spectral modelling. (DOCX $20 \mathrm{~kb}$ )

\section{Acknowledgements}

Not applicable.

\section{Funding}

We acknowledge financial support by Deutsche Forschungsgemeinschaft within the funding programme Open Access Publishing, by the BadenWürttemberg Ministry of Science, Research and the Arts and by RuprechtKarls-Universität Heidelberg.

\section{Availability of data and materials}

The datasets used and analysed during the current study are available from the corresponding author on reasonable request.

\section{Authors' contributions}

$\mathrm{JH}, \mathrm{SA}$, and JHS conceived and designed the study. SL and JHS authorised and supervised all necessary organisational adaptations within the peer teaching programmes. JH conducted the study, analysed the data, and drafted the manuscript. All authors revised the draft critically, approved the final manuscript, and accept accountability for all aspects of the work

\section{Authors' information}

$J H, M . S c .$, is a research associate in the Department of General Internal Medicine and Psychosomatics, Heidelberg University Hospital, Germany. He is responsible for developing, organising, and teaching didactic seminars for student peer tutors. His research interests are medical education as well as student stress and coping.

SA, M.Sc., M.A., is a research associate in the Department of General Internal Medicine and Psychosomatics, Heidelberg University Hospital, Germany. Her research interests are in medical education, experiential teaching and learning, physician-patient communication, and factors influencing student success.

$\mathrm{SL}$ is a medical doctor, has a master's degree in Health Care Management and is habilitated in the field of health sciences. She is a Programme Coordinator for the undergraduate training of medical students at the Department of General Practice and Health Services Research at University Hospital Heidelberg, Germany.

JHS, PD, Dr. med., MME, is a senior physician and Head of the Psychocardiology Section in the Department of General Internal Medicine and Psychosomatics, Heidelberg University Hospital, Germany. His research interests are in psychocardiologic comorbidity, doctor-patient communication, and medical education.

\section{Ethics approval and consent to participate}

This study was approved by the ethics committee of the Medical Faculty of Ruprecht-Karls University Heidelberg with the number S-373/2016. All participants gave written informed consent. During the course of the study, we assigned deidentified pseudonyms to ensure participants' privacy and blinding in all quantitative and qualitative analyses.

\section{Consent for publication}

Not applicable.

\section{Competing interests}

The authors declare that they have no competing interests.

\section{Publisher's Note}

Springer Nature remains neutral with regard to jurisdictional claims in published maps and institutional affiliations.

\section{Author details}

${ }^{1}$ Clinic for General Internal Medicine and Psychosomatics, University Hospital Heidelberg, Im Neuenheimer Feld 410, 69120 Heidelberg, Germany. 2Department of General Practice and Health Services Research, University Hospital Heidelberg, Im Neuenheimer Feld 130.3, 69120 Heidelberg, Germany.
Received: 30 October 2018 Accepted: 15 March 2019

Published online: 02 April 2019

\section{References}

1. Ten Cate O, Durning S. Dimensions and psychology of peer teaching in medical education. Med Teach. 2007;29(6):546-52. https://doi.org/10. 1080/01421590701583816

2. Goldschmid B, Goldschmid ML. Peer teaching in higher education: a review. Higher Educ. 1976;5(1):9-33. https://doi.org/10.1007/bf01677204.

3. Moore-West M, Hennessy SA, Meilman PW, O'Donnell JF. The presence of student-based peer advising, peer tutoring, and performance evaluation programs among U.S. medical schools. Acad Med. 1990; 65(10):660-1. https://doi.org/10.1097/00001888-199010000-00018.

4. Henning JM, Weidner TG, Marty MC. Peer assisted learning in clinical education: literature review. Athl Train Educ J. 2008;3(3):84-90.

5. Topping KJ. The effectiveness of peer tutoring in further and higher education: a typology and review of the literature. Higher Educ. 1996;32(3): 321-45. https://doi.org/10.1007/bf00138870.

6. Lauter J, Branchereau S, Herzog W, Bugaj TJ, Nikendei C. Tutor-led teaching of procedural skills in the skills lab: complexity, relevance and teaching competence from the medical teacher, tutor and student perspective. Z Evid Fortbild Qual Gesundhwes. 2017;122:54-60. https:// doi.org/10.1016/j.zefq.2017.03.005

7. Ten Cate O, Durning S. Peer teaching in medical education: twelve reasons to move from theory to practice. Med Teach. 2007;29(6):591-9. https://doi.org/10.1080/01421590701606799.

8. Secomb J. A systematic review of peer teaching and learning in clinical education. J Clin Nurs. 2008;17(6):703-16. https://doi.org/10.1111/j.13652702.2007.01954x

9. Fellmer-Drüg E, Drude N, Sator M, Schultz J-H, Irniger E, Chur D, et al. Einführung eines Curriculums zur medizindidaktischen Qualifizierung von studentischen Tutorlnnen mit Abschlusszertifikat. GMS J Med Educ. 2014:31(2):1-14. https://doi.org/10.3205/zma000911.

10. Weyrich $P$, Celebi N, Schrauth M, Möltner A, Lammerding-Köppel M, Nikendei C. Peer-assisted versus faculty staff-led skills laboratory training: a randomised controlled trial. Med Educ. 2009;43(2):113-20. https://doi.org/10. 1111/j.1365-2923.2008.03252.x.

11. Nikendei C, Andreesen S, Hoffmann K, Jünger J. Cross-year peer tutoring on internal medicine wards: effects on self-assessed clinical competencies - a group control design study. Med Teach. 2009;31(2): 32-5. https://doi.org/10.1080/01421590802464452.

12. Seifert LB, Schaack D, Jennewein L, Steffen B, Schulze J, Gerlach F, et al. Peerassisted learning in a student-run free clinic project increases clinical competence. Med Teach. 2016;38(5):515-22. https://doi.org/10.3109/0142159x 2015.1105940

13. Field M, Burke JM, McAllister D, Lloyd DM. Peer-assisted learning: a novel approach to clinical skills learning for medical students. Med Educ. 2007;41(4): 411-8. https://doi.org/10.1111/j.1365-2929.2007.02713.x.

14. Ten Cate $\mathrm{O}$. A teaching rotation and a student teaching qualification for senior medical students. Med Teach. 2007;29(6):566-71. https://doi.org/10. 1080/01421590701468729.

15. Bulte C, Betts A, Garner K, Durning S. Student teaching: views of student near-peer teachers and learners. Med Teach. 2007;29(6):583-90. https://doi. org/10.1080/01421590701583824

16. Lockspeiser TM, O'Sullivan P, Teherani A, Muller J. Understanding the experience of being taught by peers: the value of social and cognitive congruence. Adv Health Sci Educ. 2008;13(3):361-72. https://doi.org/10. 1007/s10459-006-9049-8

17. Alvarez S, Schultz J-H. Practice Report / Bericht aus der Praxis: An exploration of peer tutor roles and recruitment at German medical schools. Z Evid Fortbild Qual Gesundhwes. 2017:127-128:80-4. https://doi.org/10. 1016/j.zefq.2017.10.004

18. Alvarez S, Dethleffsen K, Esper T, Horneffer A, Reschke K, Schultz J-H. An overview of peer tutor training strategies at German medical schools. Z Evid Fortbild Qual Gesundhwes. 2017;126:77-83. https://doi.org/10.1016/j.zefq. 2017.09.009.

19. Sobral DT. Cross-year peer tutoring experience in a medical school: conditions and outcomes for student tutors. Med Educ. 2002;36(11):1064-70. https://doi. org/10.1046/j.1365-2923.2002.01308.x.

20. Sobral DT. What kind of motivation drives medical students' learning quests? Med Educ. 2004;38(9):950-7. https://doi.org/10.1111/j.1365-2929.2004.01913.x. 
21. Dandavino M, Snell L, Wiseman J. Why medical students should learn how to teach. Med Teach. 2007;29(6):558-65. https://doi.org/10.1080/ 01421590701477449.

22. Rhodes D, Fogg QA, Lazarus MD. Dissecting the role of sessional anatomy teachers: A systematic literature review. Anat Sci Educ. 2018;11(4):410-26. https://doi.org/10.1002/ase.1753.

23. Ringel N, Bürmann BM, Fellmer-Drueg E, Roos M, Herzog W, Nikendei C, et al. Integriertes Peer Teaching klinischer und kommunikativer Kompetenzen: Wie bereiten wir studentische Tutoren darauf vor? Psychother Psychosom Med Psychol. 2015;65(8):288-95. https://doi.org/10.1055/s-0034-1398549.

24. Alvarez S, Schultz JH. Professional and personal competency development in near-peer tutors of gross anatomy: A longitudinal mixed-methods study. Anat Sci Educ. 2018;12(2):129-37. https://doi.org/10.1002/ase.1798.

25. Kurth RA, Klier S, Pokorny D, Jurkat HB, Reimer C. Studienbezogene Belastungen, Lebensqualität und Beziehungserleben bei Medizinstudenten. Psychotherapeut. 2007;52(5):355-61. https://doi.org/ 10.1007/s00278-007-0546-X.

26. Voltmer E, Kötter T, Spahn C. Perceived medical school stress and the development of behavior and experience patterns in German medica students. Med Teach. 2012;34(10):840-7. https://doi.org/10.3109/0142159X. 2012.706339.

27. Dahlin M, Joneborg N, Runeson B. Stress and depression among medical students: a cross-sectional study. Med Educ. 2005;39(6):594-604. https://doi. org/10.1111/j.1365-2929.2005.02176.x.

28. Selye H. Stress in health and disease. Boston: Butterworths; 1976.

29. Myers DG. Stress and health. In: Myers DG, editor. Exploring psychology. New York: Worth Publishers; 2005.

30. Charmandari E, Tsigos C, Chrousos GP. Endocrinology of the stress response. Annu Rev Physiol. 2005;67:259-84. https://doi.org/10.1146/annurev.physiol. 67.040403.120816.

31. Joels M, Baram TZ. The neuro-symphony of stress. Nat Rev Neurosci. 2009; 10(6):459-66. https://doi.org/10.1038/nrn2632.

32. Kaplan HI, Sadock BJ. Learning theory. In: Kaplan HI, Sadock BJ, editors. Sypnosis of psychiatry: behavioral sciences/clinical psychiatry. 8th ed. Philadelphia: Lippincott Williams \& Wilkins; 2000. p. 148-54.

33. Linn BS, Zeppa R. Stress in junior medical students: relationship to personality and performance. J Med Educ. 1984;59(1):7-12. https://doi.org/ 10.1097/00001888-198401000-00002.

34. Teigen KH. Yerkes-Dodson: A Law for all Seasons. Theory Psychol. 1994;4(4): 525-47. https://doi.org/10.1177/0959354394044004.

35. Niemi PM, Vainiomäki PT. Medical students' academic distress, coping, and achievement strategies during the preclinical years. Teach Learn Med. 1999; 11(3):125-34. https://doi.org/10.1207/S15328015TL110302.

36. Brähler E, Schmutzer G, Gerth K, Albani C. Psychische Gesundheit von Studierenden der Medizin. In: Brähler E, Alfermann D, Stiller J, editors. Karriereentwicklung und berufliche Belastung im Arztberuf. Göttingen: Vandenhoeck \& Ruprecht; 2008. p. 36-51.

37. Dyrbye LN, Thomas MR, Shanafelt TD. Systematic review of depression, anxiety, and other indicators of psychological distress among US and Canadian medical students. Acad Med. 2006;81(4):354-73. https://doi.org/10.1097/ 00001888-200604000-00009.

38. Fares J, Al Tabosh H, Saadeddin Z, El Mouhayyar C, Aridi H. Stress, burnout and coping strategies in preclinical medical students. N Am J Med Sci. 2016;8(2): 75-81. https://doi.org/10.4103/1947-2714.177299.

39. Kötter $T$, Tautphäus $Y$, Scherer M, Voltmer E. Health-promoting factors in medical students and students of science, technology, engineering, and mathematics: design and baseline results of a comparative longitudinal study. BMC Med Educ. 2014;14(1):134. https://doi.org/10. 1186/1472-6920-14-134

40. Erschens R, Keifenheim KE, Herrmann-Werner A, Loda T, Schwille-Kiuntke J, Bugaj TJ, et al. Professional burnout among medical students: systematic literature review and meta-analysis. Med Teach. 2018:1-12. https://doi.org/10. 1080/0142159X.2018.1457213.

41. Dinkel A, Berth $H$, Balck F. Belastungen und psychische Beschwerden von Medizinstudierenden: Ein Überblick. In: Brähler E, Alfermann D, Stiller J, editors. Karriereentwicklung und berufliche Belastung im Arztberuf. Göttingen: Vandenhoeck \& Ruprecht; 2008. p. 11-35.

42. Koehl-Hackert N, Schultz J-H, Nikendei C, Möltner A, Gedrose B, van den Bussche $\mathrm{H}$, et al. Belastet in den Beruf - Empathie und Burnout bei Medizinstudierenden am Ende des Praktischen Jahres. Z Evid Fortbild Qual Gesundhwes. 2012;106(2): 116-24. https://doi.org/10.1016/j.zefq.2012.02.020.
43. Selye H. Stress. Montreal: Acta Medical Publisher Inc.; 1950. p. 143.

44. Lazarus RS, Folkman S. Transactional theory and research on emotions and coping. Eur J Pers. 1987;1(3):141-69. https://doi.org/10.1002/per.2410010304.

45. Bugaj TJ, Cranz A, Junne F, Erschens R, Herzog W, Nikendei C. Psychosocial burden in medical students and specific prevention strategies. Ment Health Prev. 2016:4(1):24-30. https://doi.org/10.1016/.mhp.2015.12.003.

46. Ledig T, Eicher C, Szecsenyi J, Engeser P. AaL plus - ein Anamnese- und Untersuchungskurs für den vorklinischen Studienabschnitt. Z Allgemeinmed. 2014;90(2):76-80. https://doi.org/10.3238/zfa.2014.0076-0080.

47. Barrows HS. An overview of the uses of standardized patients for teaching and evaluating clinical skills. Acad Med. 1993;68(6):443-51. https://doi.org/10.1097/ 00001888-199306000-00002.

48. Barrows HS. A taxonomy of problem-based learning methods. Med Educ. 1986;20(6):481-6. https://doi.org/10.1111/j.1365-2923.1986.tb01386.x.

49. Lee KA, Kieckhefer GM. Measuring human responses using visual analogue scales. West J Nurs Res. 1989;11(1):128-32.

50. Cline ME, Herman J, Shaw ER, Morton RD. Standardization of the visual analogue scale. Nurs Res. 1992;41(6):378-80. https://doi.org/10.1097/00006199$199211000-00013$.

51. Gift AG. Visual analogue scales: measurement of subjective phenomena. Nurs Res. 1989;38(5):286-8. https://doi.org/10.1097/00006199-19890900000006.

52. Cella DF, Perry SW. Reliability and concurrent validity of three visualanalogue mood scales. Psychol Rep. 1986;59(2):827-33. https://doi.org/10. 2466/pro.1986.59.2.827.

53. Diener E, Emmons RA. The independence of positive and negative affect. J Pers Soc Psychol. 1984;47(5):1105-17. https://doi.org/10.1037/ 0022-3514.47.5.1105.

54. Watson D, Tellegen A. Toward a consensual structure of mood. Psychol Bull. 1985;98(2):219-35. https://doi.org/10.1037/0033-2909.98.2.219.

55. Thompson ER. Development and validation of an internationally reliable shortform of the positive and negative affect schedule (PANAS). J Cross-Cult Psychol. 2007;38(2):227-42. https://doi.org/10.1177/0022022106297301.

56. Watson D, Clark LA, Tellegen A. Development and validation of brief measures of positive and negative affect: the PANAS scales. J Pers Soc Psychol. 1988;54(6):1063-70. https://doi.org/10.1037/0022-3514.54.6.1063.

57. Hellhammer DH, Wüst S, Kudielka BM. Salivary cortisol as a biomarker in stress research. Psychoneuroendocrinology. 2009;34(2):163-71. https://doi. org/10.1016/j.psyneuen.2008.10.026.

58. Kudielka BM, Wüst S. Human models in acute and chronic stress: assessing determinants of individual hypothalamus-pituitary-adrenal axis activity and reactivity. Stress. 2010;13(1):1-14. https://doi.org/10.3109/ 10253890902874913

59. Kirschbaum C, Hellhammer DH. Salivary cortisol in psychobiological research: an overview. Neuropsychobiology. 1989;22(3):150-69. https://doi. org/10.1159/000118611.

60. King SL, Hegadoren KM. Stress hormones: how do they measure up? Biol Res Nurs. 2002;4(2):92-103. https://doi.org/10.1177/1099800402238334.

61. Sapolsky RM, Romero LM, Munck AU. How do glucocorticoids influence stress responses? Integrating permissive, suppressive, stimulatory, and preparative actions. Endocr Rev. 2000;21(1):55-89. https://doi.org/10.1210/edrv.21.1.0389.

62. Segerstrom SC, Miller GE. Psychological stress and the human immune system: a meta-analytic study of 30 years of inquiry. Psychol Bull. 2004;130(4):601-30. https://doi.org/10.1037/0033-2909.130.4.601.

63. Herman JP, Fiqueiredo $\mathrm{H}$, Mueller NK, Ulrich-Lai $Y$, Ostrander MM, Choi DC, et al. Central mechanisms of stress integration: hierarchical circuitry controlling hypothalamo-pituitary-adrenocortical responsiveness. Front Neuroendocrinol. 2003;24(3):151-80. https:/doi.org/10.1016/j.yfrne.2003.07.001.

64. Kirschbaum C, Hellhammer DH. Salivary cortisol. Encyclopedia of Stress. 2000;3: 379-83.

65. Vining RF, McGinley RA, Maksvytis JJ, Ho KY. Salivary cortisol: a better measure of adrenal cortical function than serum cortisol. Ann Clin Biochem. 1983;20(6):32935. https://doi.org/10.1177/000456328302000601.

66. Galard R, Gallart JM, Catalan R, Schwartz S, Arguello JM, Castellanos JM. Salivary cortisol levels and their correlation with plasma ACTH levels in depressed patients before and after the DST. Am J Psychiatry. 1991;148(4):505-8. https:// doi.org/10.1176/ajp.148.4.505.

67. Kirschbaum C, Hellhammer DH. Salivary cortisol in psychoneuroendocrine research: recent developments and applications. Psychoneuroendocrinology. 1994;19(4):313-33. https://doi.org/10.1016/03064530(94)90013-2. 
68. Lupien SJ, McEwen BS, Gunnar MR, Heim C. Effects of stress throughout the lifespan on the brain, behaviour and cognition. Nat Rev Neurosci. 2009; 10(6):434-45. https://doi.org/10.1038/nrn2639.

69. Ulrich-Lai YM, Herman JP. Neural regulation of endocrine and autonomic stress responses. Nat Rev Neurosci. 2009;10(6):397-409. https://doi.org/10. 1038/nrn2647.

70. Poll E-M, Kreitschmann-Andermahr I, Langejuergen Y, Stanzel S, Gilsbach JM, Gressner A, et al. Saliva collection method affects predictability of serum cortisol. Clin Chim Acta. 2007;382(1-2):15-9. https://doi.org/10.1016/j.cca. 2007.03.009.

71. Lovallo WR, Whitsett TL, Al'Absi M, Sung BH, Vincent AS, Wilson MF. Caffeine stimulation of cortisol secretion across the waking hours in relation to caffeine intake levels. Psychosom Med. 2005;67(5):734-9. https://doi.org/10.1097/01.psy.0000181270.20036.06.

72. Lane JD, Pieper CF, Phillips-Bute BG, Bryant JE, Kuhn CM. Caffeine affects cardiovascular and neuroendocrine activation at work and home. Psychosom Med. 2002;64(4):595-603. https://doi.org/10.1097/01.PSY. 0000021946.90613.DB.

73. Thayer JF, Hall M, Sollers JJ III, Fischer JE. Alcohol use, urinary cortisol, and heart rate variability in apparently healthy men: evidence for impaired inhibitory control of the HPA axis in heavy drinkers. Int J Psychophysiol. 2006;59(3):244-50. https://doi.org/10.1016/j.jpsycho.2005.10.013.

74. Adinoff B, Ruether K, Krebaum S, Iranmanesh A, Williams MJ. Increased salivary cortisol concentrations during chronic alcohol intoxication in a naturalistic clinical sample of men. Alcohol Clin Exp Res. 2003;27(9):1420-7. https://doi.org/10.1097/01.ALC.0000087581.13912.64.

75. Rohleder N, Kirschbaum C. The hypothalamic-pituitary-adrenal (HPA) axis in habitual smokers. Int J Psychophysiol. 2006;59(3):236-43. https://doi.org/10. 1016/j.ijpsycho.2005.10.012

76. Steptoe A, Ussher M. Smoking, cortisol and nicotine. Int J Psychophysiol. 2006;59(3):228-35. https://doi.org/10.1016/j.ijpsycho.2005.10.011.

77. Gonzalez-Bono E, Rohleder N, Hellhammer DH, Salvador A, Kirschbaum C. Glucose but not protein or fat load amplifies the cortisol response to psychosocial stress. Horm Behav. 2002;41(3):328-33. https://doi.org/10.1006/ hbeh.2002.1766.

78. Kudielka BM, Broderick JE, Kirschbaum C. Compliance with saliva sampling protocols: electronic monitoring reveals invalid cortisol daytime profiles in noncompliant subjects. Psychosom Med. 2003;65(2):313-9. https://doi.org/ 10.1097/01.PSY.0000058374.50240.BF.

79. Levi T, Akkerstedt L. Circadian rhythms in the secretion of cortisol, adrenaline and noradrenaline. Eur J Clin Investig. 1978;8(2):57-8. https://doi.org/10. 1111/j.1365-2362.1978.tb00811.x.

80. Thayer JF, Åhs F, Fredrikson M, Sollers lii JJ, Wager TD. A meta-analysis of heart rate variability and neuroimaging studies: implications for heart rate variability as a marker of stress and health. Neurosci Biobehav Rev. 2012;36(2):747-56. https://doi.org/10.1016/j.neubiorev.2011.11.009.

81. Rajendra Acharya U, Paul Joseph K, Kannathal N, Lim CM, Suri JS. Heart rate variability: a review. Med Biol Eng Comput. 2006;44(12):1031-51. https://doi. org/10.1007/s11517-006-0119-0.

82. Thayer JF, Yamamoto SS, Brosschot JF. The relationship of autonomic imbalance, heart rate variability and cardiovascular disease risk factors. Int J Cardiol. 2010;141(2):122-31. https://doi.org/10.1016/j.ijcard.2009.09.543.

83. Jarczok MN, Jarczok M, Mauss D, Koenig J, Li J, Herr RM, et al. Autonomic nervous system activity and workplace stressors-a systematic review. Neurosci Biobehav Rev. 2013;37(8):1810-23. https://doi.org/10.1016/..neubiorev. 2013.07.004.

84. Chandola T, Heraclides A, Kumari M. Psychophysiological biomarkers of workplace stressors. Neurosci Biobehav Rev. 2010;35(1):51-7. https://doi.org/10. 1016/j.neubiorev.2009.11.005.

85. Jarczok MN, Kleber ME, Koenig J, Loerbroks A, Herr RM, Hoffmann K et al. Investigating the associations of self-rated health: heart rate variability is more strongly associated than inflammatory and other frequently used biomarkers in a cross sectional occupational sample. PLoS One. 2015;10(2):1-19. https://doi.org/10.1371/journal.pone.0117196.

86. Task Force of the European Society of Cardiology and the North American Society of Pacing and Electrophysiology. Heart rate variability standards of measurement, physiological interpretation, and clinical use. Eur Heart J. 1996; 17:354-81. https://doi.org/10.1093/oxfordjournals.eurheartj.a014868.

87. Williams DP, Jarczok MN, Ellis RJ, Hillecke TK, Thayer JF, Koenig J. Two-week test-retest reliability of the polar ${ }^{\circledR} \mathrm{RS} 800 \mathrm{CX}^{\mathrm{TM}}$ to record heart rate variability. Clin Physiol Funct Imaging. 2017;37(6):776-81. https://doi.org/10.1111/cpf.12321.
88. Giles D, Draper N, Neil W. Validity of the polar V800 heart rate monitor to measure RR intervals at rest. Eur J Appl Physiol. 2016;116:563-71. https://doi. org/10.1007/s00421-015-3303-9.

89. Thayer JF, Hansen AL, Johnsen BH. Noninvasive assessment of autonomic influences on the heart: impedance cardiography and heart rate variability In: Luecken LJ, Gallo LC, Luecken LJ, Gallo LC, editors. Handbook of physiological research methods in health psychology. Thousand Oaks: Sage; 2008. p. 183-209.

90. van der Ploeg MM, Koenig J, Tarvainen MP, Thayer JF. From individual output to pooled data. J Psychophysiol. 2017:1-3. https://doi.org/10.1027/ 0269-8803/a000196.

91. Tarvainen MP, Niskanen J-P, Lipponen JA, Ranta-Aho PO, Karjalainen PA. Kubios HRV - heart rate variability analysis software. Comput Methods Prog Biomed. 2014;113(1):210-20. https://doi.org/10.1016/j.cmpb.2013.07.024.

92. Tarvainen MP, Ranta-Aho PO, Karjalainen PA. An advanced detrending method with application to HRV analysis. IEEE Trans Biomed Eng. 2002;49(2): 172-5. https://doi.org/10.1109/10.979357.

93. Esperer HC, Hollenbach P, Esperer HD. Kann die 24-h-HRV im Zeitbereich aus Kurzzeit-EKG-Aufzeichnungen zuverlässig abgeschätzt werden? In: Hottenrott K, editor. Herzfrequenzvariabilität: Methoden und Anwendungen in Sport und Medizin Schriften der Deutschen Vereinigung für Sportwissenschaften, vol. 162. Hamburg: Czwalina; 2006. p. 132-42.

94. McCrae RR, Costa PT Jr. A five-factor theory of personality. In: Pervin LA, John OP, editors. Handbook of personality: theory and research. 2nd ed. New York: Guilford Press; 1999. p. 139-53.

95. John OP, Donahue EM, Kentle RL. The big five inventory — versions 4a and 54. Berkeley: University of California, Berkeley, Institute of Personality and Social Research; 1991.

96. Rammstedt B, John OP. Kurzversion des Big Five Inventory (BFI-K): Entwicklung und Validierung eines ökonomischen Inventars zur Erfassung der fünf Faktoren der Persönlichkeit. Diagnostica. 2005;51(4):195-206. https://doi.org/10.1026/ 0012-1924.51.4.195.

97. Rice KG, Richardson CME, Tueller S. The short form of the revised almost perfect scale. J Pers Assess. 2014;96(3):368-79. https:/doi.org/10.1080/ 00223891.2013 .838172

98. Slaney RB, Rice KG, Mobley M, Trippi J, Ashby JS. The revised almost perfect scale. Meas Eval Couns Dev. 2001;34(3):130-45.

99. Wagnild GM, Young HM. Development and psychometric evaluation of the resilience scale. J Nurs Meas. 1993;1(2):165-78.

100. Leppert K, Koch B, Brähler E, Strauß B. Die Resilienzskala (RS) - Überprüfung der Langform RS-25 und einer Kurzform RS-13. Klin Diagn Eval. 2008;1(2): 226-43.

101. Collins NL, Read SJ. Adult attachment, working models, and relationship quality in dating couples. J Pers Soc Psychol. 1990;58(4):644-63. https://doi.org/ 10.1037/0022-3514.58.4.644

102. Schmidt S, Strauß B, Höger D, Brähler E. Die Adult Attachment Scale (AAS) Teststatistische Prüfung und Normierung der deutschen Version. Psychother Psychosom Med Psychol. 2004;54(9):375-82. https://doi.org/10.1055/s-2003815000.

103. Schulz P, Schlotz W, Becker P. Trierer Inventar zum chronischen Stress: TICS Göttingen: Hogrefe; 2004.

104. Eid M, Gollwitzer M, Schmitt M. Statistik und Forschungsmethoden. 4th ed. Weinheim: Beltz; 2015

105. Maas CJM, Hox JJ. Robustness issues in multilevel regression analysis. Statistica Neerlandica. 2004;58(2):127-37. https://doi.org/10.1046/j.0039-0402. 2003.00252.x

106. McCoach DB. Hierarchical linear modeling. In: Hancock GR, editor. The reviewer's guide to quantitative methods in the social sciences. London: Routledge; 2010. p. 123-40.

107. Dempster AP, Laird NM, Rubin DB. Maximum likelihood from incomplete data via the EM algorithm. J Roy Stat Soc Ser B (Stat Method). 1977;39(1):1-38.

108. Mayring P. Qualitative Inhaltsanalyse: Grundlagen und Techniken. 12th ed Weinheim: Beltz; 2015

109. Nunan D, Sandercock GRH, Brodie DA. A quantitative systematic review of normal values for short-term heart rate variability in healthy adults. Pacing Clin Electrophysiol. 2010;33(11):1407-17. https://doi.org/10.1111/j.1540-8159. 2010.02841.x.

110. Huhn D, Schmid C, Erschens R, Junne F, Herrmann-Werner A, Möltner A, et al. A comparison of stress perception in international and local first semester medical students using psychometric, psychophysiological, and 
humoral methods. Int J Environ Res Public Health. 2018;15(2820):1-16. https://doi.org/10.3390/ijerph15122820.

111. Erschens R, Herrmann-Werner A, Keifenheim KE, Loda T, Bugaj TJ, Nikendei $C$, et al. Differential determination of perceived stress in medical students and high-school graduates due to private and training-related stressors. PLoS One. 2018;13(1):e0191831. https://doi.org/ 10.1371/journal.pone.0191831.

112. Haldorsen H, Bak NH, Dissing A, Petersson B. Stress and symptoms of depression among medical students at the University of Copenhagen. Scand J of Public Health. 2014;42(1):89-95. https://doi.org/10.1177/ 1403494813503055.

113. O'Reilly E, McNeill KG, Mavor Kl, Anderson K. Looking beyond personal stressors: an examination of how academic stressors contribute to depression in Australian graduate medical students. Teach Learn Med. 2014; 26(1):56-63. https://doi.org/10.1080/10401334.2013.857330.

114. Holm S. A simple sequentially rejective multiple test procedure. Scand J Stat. 1979;6(2):65-70. https://doi.org/10.2307/4615733.

Ready to submit your research? Choose BMC and benefit from:

- fast, convenient online submission

- thorough peer review by experienced researchers in your field

- rapid publication on acceptance

- support for research data, including large and complex data types

- gold Open Access which fosters wider collaboration and increased citations

- maximum visibility for your research: over $100 \mathrm{M}$ website views per year

At $\mathrm{BMC}$, research is always in progress.

Learn more biomedcentral.com/submissions 